\title{
Smith-Magenis syndrome: a new contiguous gene syndrome. Report of three new cases
}

\author{
A Moncla, M O Livet, M Auger, J F Mattei, M G Mattei, F Giraud
}

\begin{abstract}
Interstitial deletion of the short arm of chromosome 17 was detected in three patients. They all had a similar phenotype with mental retardation, behavioural problems, facial dysmorphism, brachycephaly, a broad face with a flat midface, and short and broad hands. All three cases were ascertained over a six month period by two neuropaediatricians aware of this specific anomaly, which suggests that this microdeletion is not particularly rare. Comparison of the clinical and cytogenetic findings in a total of 24 patients allows a new contiguous gene syndrome to be defined that only high resolution analysis can detect. In two cases, molecular analysis confirmed the cytogenetic results. The Charcot-Marie-Tooth type Ia gene has recently been localised to the $17 \mathrm{p} 11.2$ sub-band.
\end{abstract}

The introduction in the early 1980 s of prometaphase analysis led to the identification of submicroscopic chromosomal anomalies. Small deletions or duplications have been detected in some well delineated syndromes, such as Prader-Willi syndrome, Angelman syndrome, Miller-Diecker syndrome, and Beckwith-Wiedemann syndrome, and have also been found to be at the origin of new clinical syndromes.

Smith et $a l,{ }^{1}$ in 1982 , first described an interstitial deletion in the proximal short arm of chromosome 17: $\operatorname{del}(17)(\mathrm{p} 11.2)$. The $17 \mathrm{p} 11.2$ band was deleted in two unrelated patients presenting with cleft palate and cardiac malformation. In 1984, Patil and Bartley ${ }^{2}$ reported a smaller deletion in the $17 \mathrm{p} 11.2$ subband, del(17)(p11.2-p11.2), in a single patient with mental and growth retardation, hypotonia, hearing

INSERM U242 and Centre de Génétique Médicale, Hôpital d'Enfants de la Timone, 13385 Marseille Cedex 5, France.

A Moncla, M O Livet, M Auger, J F Mattei, M G Mattei, F Giraud

Correspondence to Dr Moncla.

Received for publication 16 December 1990.

Revised version accepted for publication 5 February 1991. loss, and facial dysmorphism. This microdeletion has now been reported in 21 patients $\mathrm{s}^{2-7}$ and a new clinical syndrome has emerged. Thus it can be assumed that deletion $17 \mathrm{p} 11.2$ is not such a rare constitutional structural chromosomal aberration.

We present three new patients with partial 17p11.2 deletion and review previously published cases. The three new cases confirm that the clinical spectrum of the syndrome is specific enough to lead to clinical diagnosis at about 3 years of age.

\section{Case reports}

CASE 1

The patient, a boy, was born at term after an uncomplicated pregnancy. The parents, a 24 year old mother and a 25 year old father, were both healthy. He was the second child of this couple, the first was stillborn at 7 months of gestation. The couple had two other normal children, a boy and a girl.

At birth his weight was $2800 \mathrm{~g}$, length $47 \mathrm{~cm}$, and head circumference $31.5 \mathrm{~cm}$. The Apgar score was normal. The neonatal period was unremarkable, but the parents described him as being "too calm a baby". Slight motor delay was observed during this period; he sat at 10 months and walked at 16 months. He spoke single words at 2 years. Delayed development became increasingly obvious with age.

At 3 years, he was referred to a neuropaediatric clinic for evaluation of his speech delay and behavioural disturbance. He spoke only about 20 isolated words. He was hyperactive with a very short attention span and frequent temper tantrums. He showed psychotic behaviour with repetitive activity, making abnormal noises with his nose and tongue, bruxism, and insomnia.

On physical examination, his height was $88 \mathrm{~cm}$ ( $-2 \mathrm{SD})$, weight $13 \mathrm{~kg}$, and head circumference $48 \mathrm{~cm}(-2 \mathrm{SD})$. He was brachycephalic with frontal bossing, mild facial hypoplasia, mild epicanthus, a short philtrum, broad nasal bridge, downturned mouth, and small, turned under ears. His voice was hoarse and low pitched. The hands were short and broad with bilateral clinodactyly of the fifth fingers. Bilateral testicular ectopia was present. Audiogram was normal and the EEG subnormal with slow 
rhythms. Psychomotor testing using the Terman Merill scale at $6 \cdot 5$ years gave a score of 65 .

\section{CASE 2}

The patient, a girl, was the second child of healthy parents; the mother was 35 and the father 31 years old. The first child was normal. The patient was born at term after an uncomplicated pregnancy. Her birth weight was $3200 \mathrm{~g}$, height $47 \mathrm{~cm}$, and head circumference $35 \mathrm{~cm}$. She developed respiratory distress owing to a pneumothorax but recovered quickly.

When she was 8 days old she was referred to the Medical Genetics Centre because of facial dysmorphism. She was brachycephalic with a broad, flat face, epicanthus, strabismus, a broad nasal bridge, small nose, small philtrum, carp shaped mouth, micrognathia, and low set ears with hypoplastic helices. Karyotyping with $\mathrm{R}$ banding was performed and found to be normal. During her first year she was very quiet and she walked at 19 months.

When she was 3 years old, she was examined in a neuropaediatric department for speech delay and behavioural problems. She was overactive and anxious with poor language development; she used only single words. Physical examination showed normal growth: weight $15 \mathrm{~kg}$ (+1 SD), height $90 \mathrm{~cm}$ $(-1 \mathrm{SD})$, and head circumference $49 \mathrm{~cm}$. Facial dysmorphism was increasingly obvious with age (fig 1). The hands were short, she had genu valgum, and her feet were flat and short with partial syndactyly of toes $2 / 3$. Her voice was hoarse. Audiogram showed a moderate conductive hearing loss. Serous otitis media was treated with myringotomy tubes. EEG was subnormal with slow rhythms. Psychomotor testing was possible at 4.5 years and the Terman Merill scale showed moderate mental retardation with full scale IQ of 65 .

\section{CASE 3}

The patient, a girl, was born at term after a normal pregnancy. The mother was 23 years old and the father 24. Birth weight was $3300 \mathrm{~g}$, height $49 \mathrm{~cm}$, and head circumference $35 \mathrm{~cm}$. The family history was unremarkable. She sat at 8 months and walked at 19 months.

When she was 30 months old, she was evaluated in a neuropaediatric department because of marked speech delay: she was only able to say "mam". She was hyperactive, irritable, and autoaggressive, with no concentration span. She made frequent guttural noises.

Physical examination showed a height of $88 \mathrm{~cm}$ ( $-1 \mathrm{SD}$ ), weight of $13 \mathrm{~kg}$, and head circumference of $49.5 \mathrm{~cm}$. The facial dysmorphism (fig 2) comprised brachycephaly with malar hypoplasia, strabismus, mild epicanthus, broad nasal bridge, small nose with anteverted nostrils, prominent upper lip, small philtrum, macrostomia with carp shaped mouth, highly arched palate, micrognathia, and small ears with abnormally attached superior helices. Frequent otitis media was treated with myringotomy tubes. The hands and feet were broad and short with partial syndactyly of toes $3 / 4$ and she had genu valgum. Hyperkeratosis was present with mild hirsutism. Neurological examination showed hypertonic Achilles tendons and brisk reflexes. CT scan
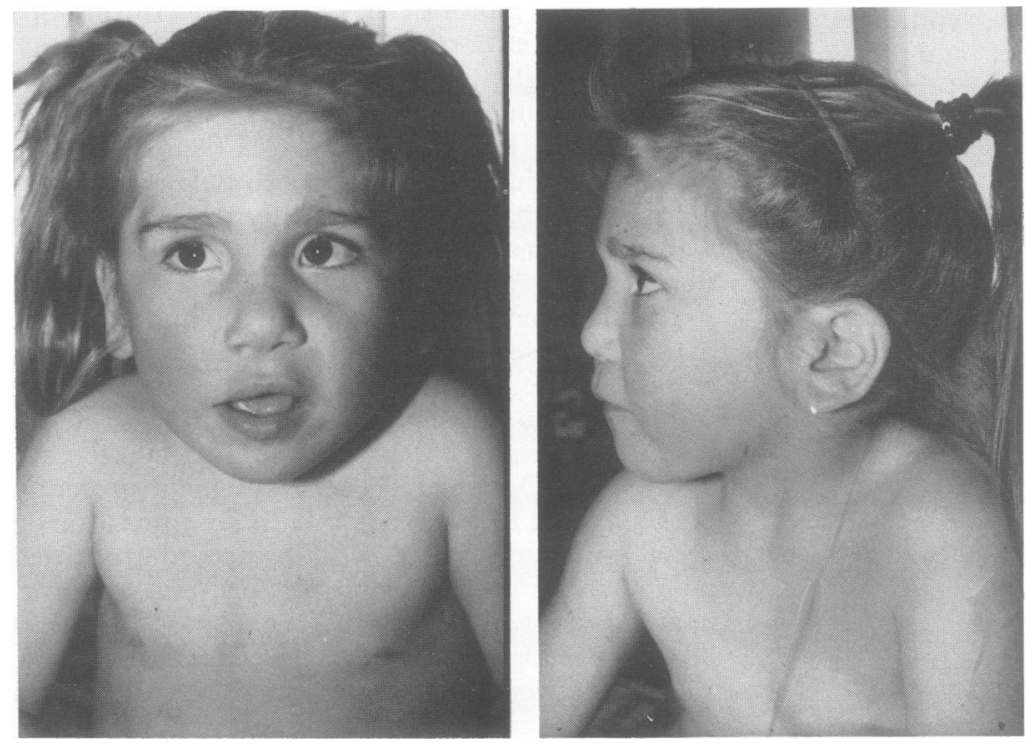

Figure 1 Front and lateral view of case 2 aged 5 years. 

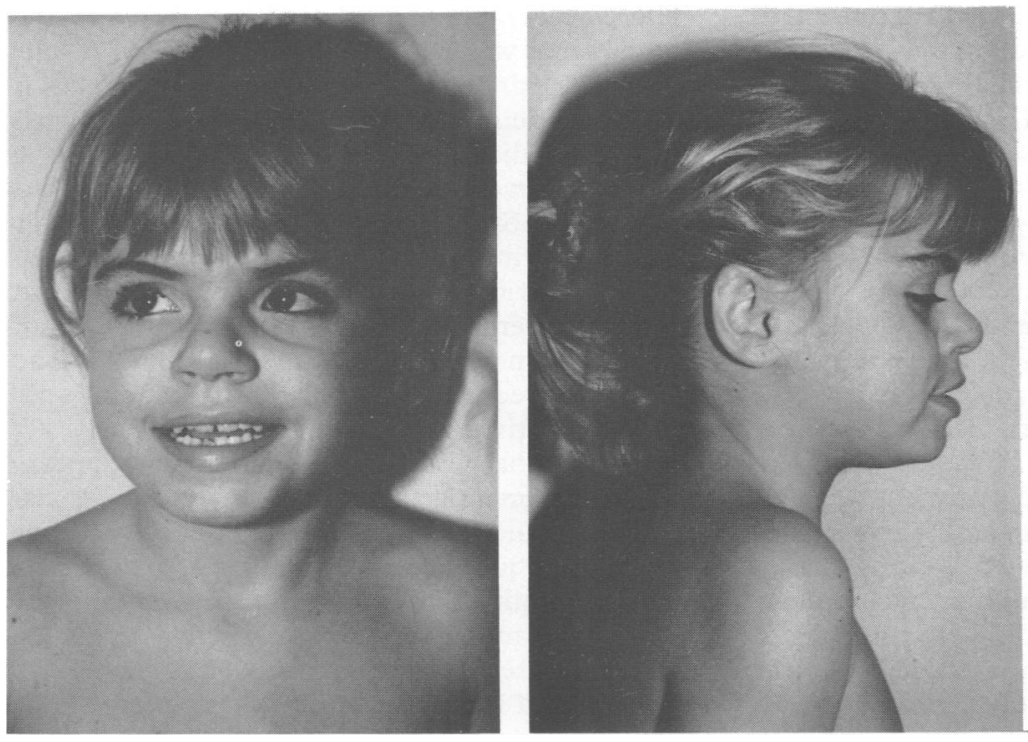

Figure 2 Front and lateral view of case 3 aged 8 years.

was normal. Routine cytogenetic analysis with $R$ banding failed to show any anomaly.

At the age of 8 years, she was examined by the neuropaediatricians. Because of the clinical similarities with recently diagnosed cases 1 and 2 , we decided to re-evaluate her karyotype with high resolution banding.

\section{CYTOGENETIC STUDIES}

In these three cases, chromosomal studies were performed on phytohaemagglutinin stimulated lymphocytes, with both standard and high resolution techniques. In the standard technique the lymphocytes were cultured for 72 hours and harvested by standard methods. $\mathrm{R}$ banding was performed by heat controlled denaturation and Giemsa staining. No precise chromosomal rearrangement could be detected in any of the three cases but in cases 1 and 3 there was a query concerning the short arm of one chromosome 17, which looked slightly shorter than the other.

High resolution banding was performed according to Camargo and Cervenka. ${ }^{8}$ Lymphocytes were synchronised with methotrexate and released by BrdU. RBB banded chromosomes were obtained by the fluorochrome-photolysis-Giemsa technique ${ }^{8}$ and an interstitial deletion in the proximal part of chromosome 17 short arm involving band p11.2 was seen in each case (fig 3 ).

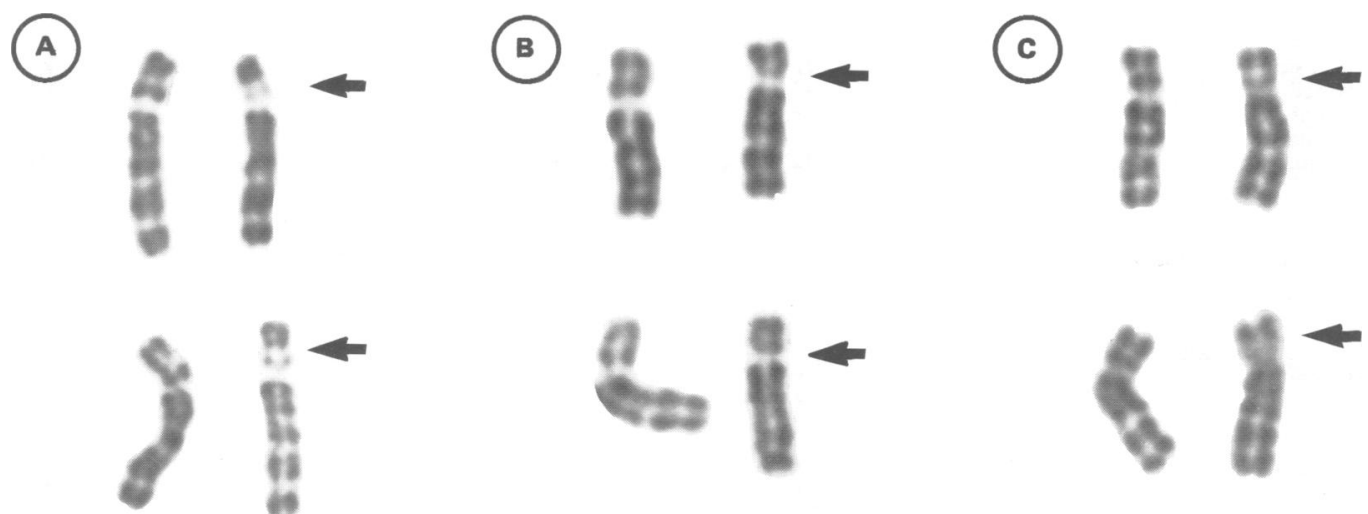

Figure $3 R$ banded chromosomes 17 of case $1(A)$, case $2(B)$, and case $3(C)$. The normal 17 is on the left and the deleted 17 on the right in each case. 
In case 1 , about $50 \%$ of the $17 \mathrm{p} 11.2$ band seemed to be deleted. The size of the deletion in cases 2 and 3 was difficult to determine accurately but seemed to be slightly smaller than in case 1 .

\section{Discussion}

High resolution cytogenetics have led to the definition of a new recognisable syndrome comprising a distinct clinical phenotype and microdeletion (17p11.2). We have described three children evaluated in the Department of Neuropaediatrics at about 3 years of age because of speech delay associated with behavioural disturbances. Case 1 was also referred to the medical genetics department because of his facial dysmorphism. Standard karyotyping showed an anomaly of $17 \mathrm{p}$ which was confirmed and refined by high resolution banding techniques. Because of their clinical similarities with case 1 , and despite a normal karyotype using standard techniques, both cases 2 and 3 were reassessed cytogenetically using high resolution banding. A 17 p11.2 microdeletion was detected in the two cases, confirming the clinical diagnosis.
The considerable clinical similarity between the three patients was remarkable. Comparison of our cases with 21 previously published cases ${ }^{1-7}$ makes it possible to delineate the clinical features which suggest this diagnosis (table). All patients have moderate to severe mental retardation with marked speech delay. Speech is more affected than motor ability as walking usually starts between 18 and 24 months. Behavioural disturbances are always found including hyperactivity with short attention span, irritability, and aggressiveness. Some autistic features are frequent with self-mutilation and selfstimulation activity.

All patients have a strikingly similar facial appearance. A combination of brachycephaly, mild facial hypoplasia, and broad nasal bridge is always observed. Frequent features are apparent telecanthus, short philtrum with carp shaped mouth, low set and malformed ears, and mandibular prognathism. The degree of prognathism, however, is age dependent and is present in the older patients. The youngest patients have micrognathia rather than prognathism. ${ }^{3}$ The voice is hoarse with a deep, rasping quality, as pointed out by Smith $e t a l,{ }^{3}$ and

Smith-Magenis syndrome: clinical findings in 21 patients with deletion 17p11.2.

\begin{tabular}{|c|c|c|c|c|c|}
\hline & \multirow[b]{2}{*}{ Previous cases } & \multicolumn{3}{|c|}{ Present report } & \multirow[b]{2}{*}{ Total } \\
\hline & & Case 1 & Case 2 & Case 3 & \\
\hline $\begin{array}{l}\text { Sex (ratio } F / M \text { ) } \\
\text { Age examined }\end{array}$ & $\begin{aligned} \cong & 1(9 \mathrm{~F} / 12 \mathrm{M}) \\
& 3 \mathrm{mth}-62 \mathrm{y}\end{aligned}$ & $\begin{array}{l}M \\
3 y\end{array}$ & $\underset{3 y}{F}$ & $\begin{array}{c}F \\
8 y\end{array}$ & $3 \mathrm{mth}-62 \mathrm{y}$ \\
\hline $\begin{array}{l}\text { Mental retardation } \\
\text { Speech delay } \\
\text { Hyperactivity } \\
\text { Behavioural problems }\end{array}$ & $\begin{array}{l}18 / 18 \\
17 / 17 \\
14 / 17\end{array}$ & $\begin{array}{l}+ \\
+ \\
+\end{array}$ & $\begin{array}{l}+ \\
+ \\
+\end{array}$ & $\begin{array}{l}+ \\
+ \\
+\end{array}$ & $\begin{array}{l}21 / 21 \\
21 / 21 \\
17 / 20\end{array}$ \\
\hline $\begin{array}{l}\text { Craniofacial } \\
\text { Brachycephaly } \\
\text { Mild facial hypoplasia } \\
\text { Broad face } \\
\text { Prominent forehead } \\
\text { Broad nasal bridge } \\
\text { Carp shaped mouth } \\
\text { Micrognathia } \\
\text { Prognathism } \\
\text { Malformed ears } \\
\text { Strabismus } \\
\text { Epicanthus } \\
\text { Telecanthus }\end{array}$ & $\begin{array}{r}20 / 21 \\
19 / 21 \\
17 / 19 \\
14 / 21 \\
19 / 21 \\
16 / 18 \\
5 / 20 \\
12 / 20 \\
13 / 19 \\
6 / 16 \\
5 / 20 \\
12 / 20\end{array}$ & $\begin{array}{l}+ \\
+ \\
- \\
+ \\
+ \\
+ \\
+ \\
\overline{+} \\
- \\
+ \\
-\end{array}$ & $\begin{array}{l}+ \\
+ \\
+ \\
- \\
+ \\
+ \\
+ \\
- \\
+ \\
+ \\
+ \\
-\end{array}$ & $\begin{array}{l}+ \\
+ \\
+ \\
- \\
+ \\
+ \\
- \\
+ \\
+ \\
+ \\
+\end{array}$ & $\begin{array}{r}23 / 24 \\
22 / 24 \\
19 / 21 \\
15 / 22 \\
22 / 24 \\
19 / 21 \\
7 / 23 \\
13 / 23 \\
16 / 23 \\
8 / 19 \\
7 / 23 \\
13 / 23\end{array}$ \\
\hline $\begin{array}{l}\text { Limbs } \\
\text { Short/broad hands } \\
\text { Digital anomalies (clinodactyly/syndactyly) }\end{array}$ & $\begin{array}{l}14 / 15 \\
13 / 18\end{array}$ & $\begin{array}{l}+ \\
+\end{array}$ & $\begin{array}{l}+ \\
+\end{array}$ & $\begin{array}{l}+ \\
+\end{array}$ & $\begin{array}{l}17 / 18 \\
16 / 21\end{array}$ \\
\hline Growth/development & $14 / 21$ & + & - & - & $15 / 24$ \\
\hline $\begin{array}{l}\text { Central nervous system } \\
\text { Hypotonia } \\
\text { Seizures }\end{array}$ & $\begin{array}{l}6 / 14 \\
6 / 9\end{array}$ & - & - & $\overline{+}$ & $\begin{array}{l}6 / 17 \\
7 / 12\end{array}$ \\
\hline $\begin{array}{l}\text { Other } \\
\text { Hearing loss } \\
\text { Coarse voice } \\
\text { Heart murmur } \\
\text { Genital anomalies } \\
\text { Cleft palate }\end{array}$ & $\begin{array}{r}10 / 20 \\
9 / 14 \\
7 / 20 \\
7 / 20 \\
2 / 21\end{array}$ & $\begin{array}{l}- \\
+ \\
- \\
-\end{array}$ & $\begin{array}{l}+ \\
+ \\
- \\
-\end{array}$ & $\begin{array}{l}+ \\
+ \\
- \\
-\end{array}$ & $\begin{array}{r}12 / 22 \\
12 / 17 \\
7 / 23 \\
7 / 23 \\
2 / 24\end{array}$ \\
\hline
\end{tabular}


may be a good diagnostic clue. Otitis media is frequent with conductive hearing loss. The hands are short and broad with brachydactyly, clinodactyly of the fifth fingers, and syndactyly of the toes.

Other clinical signs have been reported. Growth retardation is present in about $50 \%$ of patients. Ophthalmological anomalies have also been described, ${ }^{7}$ as have dermatological signs like hyperkeratosis and hirsutism. ${ }^{6}$ Visceral malformations, facial clefts, congenital heart defects, cardiac murmur, and renal and genital anomalies are rare.

The sex ratio is equal: among the 24 reported cases, 13 were females and 14 were males, as reported by Lockwood et al. ${ }^{6}$ The ages at which the patients have been described range from the neonatal period to 62 years. This explains the phenotypic variability, particularly for facial dysmorphism. In our case 2, the typical facial features were present at birth but the diagnosis was difficult without the other specific signs. A review of published reports indicates that diagnosis is clinically possible at 3 years when phenotypic expression of the three major signs is complete: speech delay, facial dysmorphism, and short hands. This syndrome should be considered when evaluating children with speech delay and behavioural disturbances and knowledge of these characteristic signs allows high resolution analysis to be focused on a specific chromosome. The frequency of this microdeletion is difficult to establish but appears to be high. Our three patients were identified over a 6 month period in a single centre and Lockwood et $a l^{6}$ reported a similar frequency.

High resolution analysis is necessary to reveal this microdeletion because of its small size. The deletion involved at least $50 \%$ of band $17 \mathrm{p} 11.2$ both in our cases and the other previously published cases. In two cases reported by Smith et al ${ }^{1}$ the $17 \mathrm{p} 11.2$ band was completely missing but the phenotype included cardiac defect and cleft palate.

These microdeletions always appear de novo and no parental chromosomal rearrangements have been found. In contrast with the deletion in MillerDieker syndrome, which has been localised to the distal short arm of chromosome 17 (17p13) through an inherited translocation, ${ }^{910}$ the Smith-Magenis syndrome was discovered only through the improvement in cytogenetic techniques. Four translocations involving a breakpoint in $17 \mathrm{p} 11.2$ have been reported. ${ }^{11}$ In all the cases, the unbalanced rearrangement led to a trisomy $17 \mathrm{p}$ by adjacent 1 segregation. No monosomy 17p11.2-pter has been observed, probably because this type of rearrangement is lethal. The short arm of chromosome 17 seems to be a hot spot for rearrangement in two specific regions, $17 \mathrm{p} 11.2$ and $17 \mathrm{p} 13$. This non-random distribution of breakpoints may be explained by repetitive sequences in these regions of chromosome 17. The sequences may be of Alu type found in $\mathrm{R}+$ bands, which are frequently associated with rearrangements, as described by Lehrman et al..$^{12}$ Deletion might be the consequence of asymmetrical pairing and unequal exchange arising within repeated sequences during meiosis. ${ }^{13}$

Several genes, such as the ubiquitine gene, ${ }^{14}$ the genes for the cytokeratin family, ${ }^{15}$ and the gene for Charcot-Marie-Tooth disease type Ia, have already been located in the $17 \mathrm{p} 11.2$ region. The mapping of the Charcot-Marie-Tooth disease gene was obtained by linkage analysis. ${ }^{16-18}$ Using three probes linked to the Charcot-Marie-Tooth disease gene (pEW 301, pUC 10-41, and pYNM 67, supplied by ATCC), we have shown that probes pU 10-41 and pYNM 67 are deleted in our cases 2 and 3, but neither the previously published patients, nor our three patients show any neuromuscular anomaly (Moncla et al, submitted). It is likely that the gene for CharcotMarie-Tooth disease is located outside the observed deletions. Construction of a somatic cell line is in progress for our patients.

A more sophisticated molecular approach to this new 'contiguous gene syndrome'19 is now necessary to characterise the genes involved in the deletion better.

1 Smith ACM, McGavran L, Waldstein G. Deletion of the 17 short arm in two patients with facial clefts. Am $\mathcal{F}$ Hum Genet 1982;34:410A

2 Patil SR, Bartley JA. Interstitial deletion of the short arm of chromosome 17. Hum Genet 1984;67:237-8.

3 Smith ACM, McGavran L, Robinson J, et al. Interstitial deletion of (17)(p11.2 p11.2) in nine patients. $\mathrm{Am} \mathcal{F}$ Med Genet 1986;24:393-414.

4 Stratton RF, Dobyns WB, Greenberg F, et al. Report of six additional patients with a new chromosome deletion syndrome. Am ₹ Med Genet 1986;24:421-32.

5 Hamill MA, Roberts SH, Maguire MJ, Laurence KM. Interstitial deletion of 17p11.2: case report and review. Ann Gener (Paris) 1988;31:36-8.

6 Lockwood D, Hecht F, Dowman C, et al. Chromosome subband $17 \mathrm{p} 11.2$ deletion: a minute deletion syndrome. $7 \mathrm{Med}$ Genet 1988;25:732-7.

7 Cabral de Almeida JC, Fagundes Reis D, Martins RR. Interstitial deletion of (17)(p11.2) - a microdeletion syndrome. Ann Genet (Paris) 1989;32:184-6.

8 Camargo M, Cervenka J. Patterns of DNA replication of human chromosomes. II. Replication map and replication model. $A m$ f Hum Genet 1982;34:757-80.

9 Stratton RF, Dobyns WB, Susan DA, Ledbetter DH. New chromosomal syndrome: Miller-Dieker syndrome and monosomy $17 \mathrm{p} 13$. Hum Genet 1984;67:193-200.

10 Schinzel A. Microdeletion syndromes, balanced translocations, and gene mapping. 7 Med Genet 1988;25:454-62.

11 Schrander-Stumpel C, Schrander J, Fryns JP, Hamers G. Trisomy $17 \mathrm{p}$ due to a $\mathrm{t}(8 ; 17)(\mathrm{p} 23 ; \mathrm{p} 11.2)$ pat translocation. Case report and review of the literature. Clin Genet 1990;37:148-52.

12 Lehrman MA, Russel DW, Goldstein GL, Brown MS. ExonAlu recombination deletes 5 kilobases from the low density lipoprotein receptor gene producing a null phenotype in familial hypercholesterolemia. Proc Natl Acad Sci USA 1989;83:3679-83.

13 Chandley AC. Asymmetry in chromosome pairing: a major factor in de novo mutation and the production of genetic disease in man. $\mathcal{F}$ Med Genet 1989;26:546-52. 
14 Webb GC, Baker RT, Fagan K, Board PG. Localization of the human UbB polyubiquitin gene to chromosome band 17p11.1-17p12. Am f Hum Genet 1990;46:308-15.

15 Solomon E, Barker DF. Report of the committee on the genetic constitution of chromosome 17. Cytogenet Cell Genet 1989;51:319-37.

16 Raeymaekers $\mathrm{P}$, Timmerman V, De Jonghe $\mathrm{P}$, et al. Localization of the mutation in an extended family with CharcotMarie-Tooth neuropathy (HMSNI). Am $f$ Hum Genet 1989;45:953-8.
17 Middleton P, Harding AE, Monteiro C, Berciano J, Malcolm S. Linkage of hereditary motor and sensory neuropathy type $I$ in the pericentromeric region of chromosome 17. Am $\mathcal{f} \mathrm{Hum}$ Genet 1990;46:92-4.

18 Patel P, Franco B, Garcia C, et al. Genetic mapping of autosomal dominant CMT disease in a large French Canadian kindred. Identification of new linked markers of chromosome 17. Am f Hum Genet 1990;46:801-9.

19 Schmickel RD. Contiguous gene syndromes: a component of recognisable syndromes. $\mathcal{F}$ Pediatr 1986;109:231-41. 